\title{
The Aims of Prospective Teachers in Using and Proficiency in Internet (As in the Sample of Pamukkale University Education Faculty)
}

\author{
Assoc. Prof. Ali Riza Erdem \\ Pamukkale University Education Faculty Denizli, Turkey \\ E-mail: arerdem@gmail.com
}

Received: August 1, 2011

Accepted: August 30, $2011 \quad$ Published: December 1, 2011

doi:10.5539/res.v3n2p117

URL: http://dx.doi.org/10.5539/res.v3n2p117

This text is a revised form of the Proceedings Book (pages 1091 - 1098 - volume 2) concerning the "10th International Edcational Technology Conference" which was held by Sakarya University at Boğaziçi University Campus on 26 - 28th April, 2010.

\begin{abstract}
Internet, regardless of their volumes, brands, operating system and hardware systems, internet is now considered a meeting point for millions of computers. Today, teachers and students are gradually utilizing the net in education more and more and more frequently. Therefore, this study is a descriptive search as if aims to clarify the prospective teachers (at Pamukkale University Education Faculty) level of internet knowledge and use it. The sampling was performed through sampling group method among 780 prospective teachers. Meanwhile, the data obtained in this study was piled up through a specifically developed scale which had been built up in optical reader form. After these forms were filled in, they were scanned by the optic reader and the result obtained were analyzed through the program called SPSS 11.5 (Statistical Package for Social Sciences). According to the results the prospective teachers level of internet knowledge it was "I know with $51.2 \%$ ". As for the prospective teachers three reasons in order are "search on the internet", "e-mail" and "chat".
\end{abstract}

Keywords: Teacher candidate, Internet, Know, Aims for proficiency

\section{Introduction}

Internet is a meeting point for millions of computers, regardless of their capacity, brands, software and hardware system. Therefore, it is largely considered the title of an extensive area in which gradually increasing computers and users share and load any kind of knowledge.

\subsection{The use of internet in education and "training \& education based on internet"}

Today, rapidly developing internet and computer technologies have penetrated into training and teaching systems at an incredible speed and such training and teaching system based on internet has finally managed to be regarded as a rising star and the case is going on expanding at a remarkable rate. Meanwhile, it is observable fact that teachers and students are gradually more benefitting from internet for educational purposes in which courses are performed through popular knowledge while teachers could share many documents with each other via internet. Today, remote education, tele-conference and courses, tests and exams on electronic conditions are among the most remarkable educational opportunities. When it comes to e-learning, internet is actively used from pre-school period to higher education process and the leading reasons that make e-learning alluring is that e-leading offers a remarkable flexibility in space and time along with allowing global learning. Moreover, e-learning increases qualifications of the training process with advantages in reaching sources of knowledge via exclusive multimedia technologies and internet (Oliver and Omari, 2001; Picciano, 2002; Carswell and Thomas and Petre and Plaine and Richards, 2002; Su and Bonk and Magjuka and Liu and Lee, 2005; Odabaş1 and Çoklar and Kıyıcı and Akdoğan, 2005; Alonso and Lopez and Manrique and Vines, 2005)

Following are the ways teachers could benefit from internet (Yalın, 2003): (1) they could come up with educational matters and argue their ideas while assisting each other about technical problems and headlines on training (2) they are able to utilize on-line database including teaching methods, strategies and teaching schedules (3) they could organize library projects, and use scientific database in order to choose and copy the 
suitable material through material achieves (4) by contacting to experts in their fields, teachers could make these experts available for students in order to argue their views. When it comes to students, following are the ways they could benefit from internet (Yalın, 2003): (1) they are available to reach instant knowledge with varied searches including database and other sources of knowledge (2) they could communicate with each other by using e-mail and electronic boards so as to argue on certain matters, make mail-friends and drive some collaborative works on project (3) through library, they are able to access articles on online journals as well as the lists of sources in libraries.

Prospective teachers, during the vocational training, underlined the difficulties with the use of technology on courses to which they relate insufficient equipment, enabled teaching staff in use of technology and unsatisfying technologies in classrooms and labs (Sadi and Şekerci and Kurban and Topu and Demirel and Tosun and Demirci and Göktaş, 2008). According to the study released by Çelik and Kahyaoğlu (2007), positive approaches of prospective teachers towards technology seem rather to focus on "the required qualifications in teachers that are parallel to technology", "the use of technological means in education and training process", "use of computer software's for educational purposes" and "importance of the ability for be proficient in those technological means." As for the negative approaches, they are rather observed in three groups identified as "the state of non-use of technological means in education", "reverse effects of technological means" and "the difficulty in using those means."

\subsection{The aims of prospective teachers in using and proficiency in internet}

We, in our age, are exposed to an ever-developing technological alterations, which is why it is inavailable now that prospective teachers are supposed to be proficient in "new technologies od knowledge", judging from frequently used educational expressions in WEB based education and WEB based learning. Thus, it seems an available fact that both teachers and prospective teachers should broaden mind in their careers since internet has gradually turned into a remarkable means allowing both teachers and students to instantly access exclusive sources to contribute their occupational development. Besides, it is an undeniable fact that prospective teachers who are trained in classrooms equipped with internet technologies are observed to be able to establish more socially common points with the student and teacher groups at practical primary schools than the prospective teachers who are not trained in classrooms equipped with internet technologies (Gezer, Sevim, 2006; Akın, 2007). Prospective teachers, at most, utilize internet orderly in "education", "communication" and, at least, for "commercial purposes" (Oral, 2004; Atav and Akkoyunlu and Sağlam, 2006; Çavuş and Gökdaş, 2006; Özdemir and Usta, 2007; Usta and Bozdoğan and Yıldırım, 2007). Meanwhile, according to Çevik and Yiğit's study in (2009), prospective teachers use internet for communication via e-mail or chatting programmes and, rarely, for reading e-newspapers. According to another study released by Yalçınalp and Aşkar in (2003), prospective teachers do have many lacks in searching on internet, and so they mostly prefer superficial ways.

\subsection{The problem sentence}

The following is the study subjects "What are opinions of prospective teachers in knowing about internet and aims for using it?" here are the sub-problems involved.

1. What are opinions of prospective teachers about their levels in knowing about internet?

2. What are opinions of prospective teachers about aims for using internet?

3. What are opinions of prospective teachers about their levels in knowing about internet according to

a) Gender

b) Education status

c) Grade

d) His departmant

e) The school he/she graduates

f) The place he/she acces to internet

g) How long has he/she has been connecting to internet

h) Is there a meaningfull variation of his/her daily access routine 


\section{The Method}

This study is a descriptive search aiming to clarify the level of prospective teachers at Pamukkale University Education faculty in knowing about internet and their aims to utilize internet and in this survey, due diligence is mainly taken into consideration.

\subsection{Survey and sampling}

In this study, the total field under survey is comprised of the prospective teachers at PAU Education Faculty. The number of registered students at PAU Education faculty during the education season of 2008-2009, regardless of graduate students and postgraduate students with /without thesis, is 4.408. As it doesn't seem probable to reach all individuals in the total field under survey, the data was comprised of samplings that would represent the total field of the survey. The sampling chosen from the survey was performed judging from the meaningful level of .05 . The sampling was performed through sampling group method among 780 prospective teachers.

\subsection{The means of data collection}

The data obtained in this survey was collected via a recently developed scale as well as utilizing certain documents concerning the scale which is comprised of the sections apart from the general knowledge. Besides, the scale consists of totally 21 questions, 11 of which are concerning the level of knowing about internet, and the rest of 10 of which are about the general aims for utilizing internet. The question as to the level of knowing about internet mentioned in the scale are four optioned. Below, you will these options of the scaled questions concerning the level of knowing about internet:

1) I'm not familiar - you are completely in dark about such a process or even if you are not, you don't have any ides of how to use it.

2) I'm familiar to some extent - you know about this process and you have tried it for a few times or seen otgers use internet and you feel proficient in handling/ using it when needing. However, you may require someone or a menu of assistance to orient you.

3) I know a little bit - you've used the function(s) beforehand and you could handle alone, without getting any outer assistance, even though you're sometimes mistaken, with trying and mistaking method

4) I know about internet - you are able to quickly perform the processes in problem-free, and more, could assist, others for similar steps.

The questions concerning the aims for using internet that are mentioned in the scale are comprised of 5 options as the following:

1) Never

2) Sometimes: less than once a week;

3) Frequently: at least once a week, but not daily;

4) Everday: about once a day;

5) Everday+: more than once a day.

Meanwhile, to get the creditability of the scale, expert opinion was benefitted from as well as statistically scanning to maintain the radily tangibility of the scaled questions. The fidelity of the scale applied on the sampling group was tried by Cronbach Alpha and Guttman Spilit-half techniques and the inner-integrity coefficiency of Alpha is .89 in the sub-category of the"knowing about internet", .86 in the sub-category of the "aims for using internet", while it is .90 in the whole scale.

\subsection{Analysis of the data}

The applied scale was framed in the form of optical reader and after the optical scale forms were filled in, it was evaluated by the optical reader and the parameters ontained were analyzed consistent with SPSS (Statistical Package for Social Sciences) 11.5. In addition, in order to come across satisfying answers to the sub-problems frequency, percentage, arithmetic average, T-test and variance analysis were utilized while the level intervals for the terms in the scale was obtained through the formula of $n-1$. To the parameters, the level intervals for the terms in the scale concerning the level of knowing about internet are found as 1.00-1.75 ("I'm not familiar"), 1-76-2.50 ("I'm familiar to some extent"), 2.51-3.25 ("I know a little bit"), 3.26-4.00 ("I do know about internet"). When it comes to the level intervals for the terms in the scale concerning the reasons for using internet are found as 1.00-1.80 ("Never"), 1.81-2.60 ("Sometimes"), 2.61-3.40 ("Frequently"), 3.41-4.20 ("Everday"), 4.21-5.00 ("Everday +"). 


\section{Findings}

Here are the findings of the sub-problems mentioned in the survey.

\subsection{Findings concerning the first sub-problem}

Opinions of the prospective teachers at PAU Education Faculty are "I do know about internet", as shown in the Table 1, while their opinions on knowing a opinions of prospective teachers at PAU Education faculty as to knowing about internet are "I do know about internet" (with $51.2 \%$ ), "I know a little bit" (with $27.6 \%$ ), "I'm familiar to some extent (with $17.3 \%$ ) and "Ido not know about internet" (with $4.0 \%$ ). On the table 2, you will find about their opinions as to their levels of knowing about internet.

[Insert Table 1 and Table 2 about here]

The first three term the prospective teachers at PAU Education Faculty knowing about internet are orderly "I capable of sending and receiving e-mail messages", "I'm capable of loading and opening files" and "I know how to access internet"..

\subsection{Findings concerning the second sub-problem}

General opinions of the prospective teachers at PAU Education faculty concerning the reasons for using internet are "sometimes (less than once a week)" with $34.5 \%$ while these rates are $3.1 \%$ for "everday+(more thanonce a day)", $16.2 \%$ for "everday (about once aday)", $31.4 \%$ for "frequently (at least once a week, but not everday)", and $14.9 \%$ for "never" (Table 3 ). Here are about their opnions about reasons for using internet on Table 4.

[Insert Table 3 and Table 4 about here]

The first three term the prospective teachers at PAU Education Faculty reasons for using internet are orderly "Research on the internet", "E-mail" ve "Chat".

\subsection{Findings concerning the third sub-problem}

There are findings about opinions of the prospective teachers concerning their levels of knowing about internet based on their (1) sex (2) educational status (3) grade (4) department (5) school they graduated (6) place he/she connects to internet (7) how many years have they been connecting to internet for (8) he/ she duration on internet a day:

\subsubsection{Based on the sex}

Opnions of the prospective teachers atPAU Education faculty concerning the level of knowing about internet has been observed to meaningfull vary based on sex (Table 5).

[Insert Table 5 here]

Judging from the table 5 , it could readily be deduced that male prospective teachers seem more informed concerning knowing about internet.

\subsubsection{Based on the educational status}

Education status does not indicate a meaningful variation in opinions of the prospective teachers at PAU Education Faculty concerning the levels of knowing about internet (Table 6).

[Insert Table 6 here]

\subsubsection{Based on the grade}

The grade indicates a meaningful variation in opinions of the prospective teachers at PAU Education Faculty concerning the levels of knowing about internet (Table 7 and Table 8).

\section{[Insert Table 7 and Table 8 here]}

As could be seen in the table 7, opinions of the prospective teachers, based on their grades, concerning their levels in knowing about internet indicate a variation between 2.97-3.44. judging from the " $p$ " value in the table 8 below. 05 , the variations in the averages is meaningful and among the prospective teachers, based on their grades, the most-informed group is comprised of the ones at " 5 th + year" while the least-informed group is comprised the ones at " 1 st year".

\subsubsection{Based on their departments}

Based on their departments, opinions of the prospective teachers at PAU Education Faculty indicate a meaningful distinction (Table 9 and Table 10).

[Insert Table 9 and Table 10 here] 
As seen in the table 9, opinions of the prospective teachers concerning their levels in knowing about internet shows a variance between 2.78 and 3.31. As the "p" value in the table 10 is below the .05 , the distinction of the averages is quite meaningful. Of all the departmentsat the PAU Education Faculty, the most well-informedones are from "the department of music teaching" while the least -informed prospective teachers come from "the department of social-sciences teaching"

\subsubsection{Based on the school they graduated}

Based on the school they graduated, opinions of the prospective at PAU Education Faculty concerning their knowledge in knowing about internet indicate a meaningful distinction (Table 11 and Table 12).

[Insert Table 11 and Table 12 here]

As seen in the table 11, opinions of the prospective teachers, based on the school they graduated, concerning their levels in knowing about internet indicates a variation between 2.98 and 3.30 and the variation in averages are meaningful as the "p" value in the table 12 is lower than .05 . Among the groups of prospective teachers based on the schools they graduated, the most weel-informed ones come from the "license group" while the least-informed group of prospective teachers are the ones who are "occupational Anatolian high schools".

\subsubsection{Based on the place they access to internet}

Opinions of prospective teachers, based on the place they access to internet, concerning levels in knowing about internet indicate a meaningful difference (Table 13 and Table 14).

[Insert Table 13 and Table 14 here]

As seen in the table 13, opinions of the prospective teachers, based on the place they connect to internet, concerning their level in knowing about internet indicates a variation between 2.78 and 3.38. Among the groups, the most well-informed group is comprised of ther ones who who make "connection both at home and in internet cafe and in the university" while the least well-informed group consists of the ones who make "only university connection".

\subsubsection{Based on for how many years they have connected to internet}

Opinions of the prospective teachers, based on for how many years they have connected to internet, concerning their levels in klnowing about internet indicate a meaningful distinction (Table 15 and Table 16).

\section{[Insert Table 15 and Table 16 here]}

As seen on the table 15 , opinions of the prospective teachers, based on for how many years they have connected to internet, concerning their levels in knowing about internet show a variation between 2.81 and 3.39. As the "p" value is lower than .05 on the table 16, the difference between the averages is found meaningful. Based on for how many years they have connected to internet, the most well-informed group is comprised of ones of " $5+$ years", while the least well-informed group is the prospective teachers who have made internet connection for "1 year".

3.3.8 Based on the duration on the internet a day

Opinions of the prospective teachers, based on the duration on the internet a day, concerning their levels in knowing about internet indicate a meaningful distinction (Table 17 and Table 18).

[Insert Table 17 and Table 18 here]

As seen on the table 17, opinions of the prospective teachers, based on the duration on the internet a day, concerning their levels in knowing about internet show a variation between 2.66 and 3.63. As the "p" value is lower than .05 on the table 18, the difference between the averages is found meaningful. Among the groups of prospective teachers, the most well-informed ones come from the group of " $7+$ hours", whereas the least-informed group is comprised of one on internet "less than 1 hour a day".

\section{Discussion}

Opnions of the prospective teachers concerning their level in knowing about internet is "I know (with $51.2 \%$ )". As for the first three terms about which the prospective teachers do know at best, they are orderly as following: "I know about sending and receiving e-mails", "I know about leading and opening a file on internet" and "I know how to access internet". In that way, we may conclude that prospective teachers at PAU Education Faculty should be donated with knowledge of theorical and practical use of internet in education during vocational training and formation courses because this seems as an invariable qualification for prospective teachers of the future who will be supposed to use internet in active and effective training process. 
Opinions of the prospective teachers at PAU Education faculty about their reasons for using internet are "sometimes (less than once a week)". The first three reasons of them for using internet are orderly as following: "search on internet", "e-mails" and "chatting" but reasons for "lauching a web-page" and "e-commerce" are never used. These results are also observed to match with results of similar other surveys. Namely, prospective teachers, in larger sense, prefer internet orderly for "educational purposes" and than for "communicational reasons" while "e-commerce" is used at least (Atav and Akkoyunlu and Sağlam, 2006; Çavuş and Gökdaş, 2006; Özdemir and Usta, 2007; Usta and Bozdoğan and Yıldırım, 2007). According to the survey conducted by Çevik and Yiğit in (2009), prospective teachers prefer internet for at most "e-mails" or communication" via chatting programmes, and rarely for "reading newspaper". In conclusion, it is clearly seen that prospective teachers may need a prompt training for internet use in education and training, as well.

Based on the gender, it is clearly observed that male propective teachers are more-informed than female ones concerning knowing about internet, so the latter group requires more knowledge of internet. When it comes the grade, the most-informed group is the " $5+$ year", while the least-informed ones take place in the group of " 1 st year". The result should be considered vital in that it clarifies prospective teachers get more knowledge of internet as they more further grades. As for the results based on departments, the "department of Music" ranks the leader with the most-informed prospective teachers concerning internet while the least-informed prospective teachers are at the "teaching of social sciences". Judging from the results, it could be deduced that prospective teachers at all branches should be given priority concerning knowledge of internet in sufficient level. Concerning the school they graduated from, the most-informed group is the "lecence" whereas the least-informed one is the group "occupation high-schools". About the place from which they connect to internet, ones who make connection from "both home, and the university as well as internet cafes" are considered the most-informed group whereas ones connecting "only from the university" ranks as the least -informed group. Judging from this point, we should consider that the points at which prospective teachers could access to internet in to be multipled at once. Concerning for how many years they have connected to internet, the most-informed group is the " $5+$ yers" whereas the least-informed ones are the prospective teachers of "only 1 year". Based on the duration on internet a day, the most-informed group concerning the level of knowing about internet is 7+ hours a day while the least-informed goup is "less than 1 hour a day". In addition, judging from the results, it should be stressed that more access points to internet for prospective teachers, in vocational training, by which they could obtain practical knowledge should be allocated for their use between 08.00 and 24.00 at night.

\section{References}

Akın, M. (2007). Effect of benefiting from the computer and internet technologies in compiling field knowledge (As in the Education Faculty of Erzincan). The Journal of the Education Faculty of Erzincan, 9 (2), 49-70.

Alonso, F., Lopez, G., Manrique, D. and Vines, J. M. (2005). An instructional model for Web-based e-learning education with a blended learning process approach. British Journal of Educational Technology, 36 (2), $217-235$. http://dx.doi.org/10.1111/j.1467-8535.2005.00454.x

Atav, E., Akkoyunlu, B. and Sağlam, N. (2006). Opportunities to access internet for prospective teachers and reasons for internet use. The Journal of The Education Faculty of Hacettepe University, 30, 37-44.

Carswell, L., Thomas, P., Petre, M., Blaine, P. and Richards, M. (2002). Distance education via the Internet: The student experience. British Journal of Educational Technology, $31 \quad$ (1), 29-46. http://dx.doi.org/10.1111/1467-8535.00133

Çavuş, H. and Gökdaş, İ. (2006). Gainings and reasons of the students at education faculties for beneting from internet. The Journal od The Education Faculty of Yüzüncü Yıl University, 3 (2), 56-78.

Çelik, H. C. and Kahyaoğlu, M. (2007). The groupanalysis concerningthe attitudes of prospective teachers toward technology. The Journal of Turkish Educational Sciences, 5 (4), 571-586.

Çevik, O. and Yiğit, S. (2009). Profiles of the prospective teachers at the Education Faculty-As in the Amasya University. C. Ü. Sosyal Bilimler Dergisi, 33 (1), 89-106.

Gezer, B. and Sevim, Y. (2006). Effects of internet in professional advancement for the teachers at secondary teaching: As in the Elazığ. Surveys in the Eastern Anatolia, 79-84.

Odabaşı, F., Çoklar, A. N., Kıyıcı, M. and Akdoğan, E. P. (2005). The ability to course teaching on Web in the first part of the primary school process. The Turkish Online Journal of Educational Technology (TOJET), 4 (4), 182-190. 
Oliver, R. and Omari, A. (2001). Exploring student responses to collaborating and learning in a Web-based environment. Journal of Computer Assisted Learning, 17 (1), 34-47. http://dx.doi.org/10.1046/j.1365-2729.2001.00157.x

Oral, B. (2004). States of internet use by prospective teachers, XIII. The conference of National Educational Sciences, 6-9 Temmuz 2004,The Education Faculty of İnönü University, Malatya. [Online] Available: http://www.pegema.net/dosya/dokuman/318.pdf (01.04. 2010)

Özdemir, S. M. and Usta, E. (2007). A study into the reasons of prospective teachers at primary school teaching department concerning. TSA, 11 (3), 91-110.

Picciano, A. G. (2002). Beyond student perceptions: Issues of interaction, presence, and performance in an online course. JALN, 6 (1), 21-40.

Sadi, S., Şekerci, A. R., Kurban, B., Topu, F. B., Demirel, T., Tosun, C., Demirci, T. and Göktaş, Y. (2008). Effective use of technology in teachers training: Teaching elements and opinions of prospective teachers. The Journal of Computer Technology, 1 (3), 43-49.

Su, B., Bonk, C. J., Magjuka, R. J., Liu, X. and Lee, S. (2005). The importance of interaction in Web-based education: A program level case study of online MBA courses. Journal of Interactive Online Learning, 4 (1), 1-19.

Usta, E., Bozdoğan, A. E. and Yıldırım, K. (2007). Evaluation of prospective teachersof primary school attitudes concerning internet use. The Journal of KIrşehir Education Faculty of Ahi Evran Universitiy, 8 (1), 209-222.

Yalçınalp, S. and Aşkar, P. (2003). A survey on the forms of students to use internet for the search of knowledge. The Turkish Online Journal of Educational Technology (TOJET), 2 (4), 100-107.

Yalın, H. İ. (2003). Teaching technologies and material development. Ankara: Nobel Publishing.

Table 1. The frequency values of the scores related to the opinions of prospective teachers at PAU Education Faculty concerning their levels of knowing about internet

\begin{tabular}{llll}
\hline $\begin{array}{l}\text { The level of knowing } \\
\text { about internet }\end{array}$ & Frequency & $\%$ & Level \\
\hline $3.26-4.00$ & 399 & 51.2 & I do know about internet \\
$2.51-3.25$ & 215 & 27.6 & I know a little bit \\
$1.76-2.50$ & 135 & 17.3 & I'm familiar to some extent \\
$1.00-1.75$ & 31 & 4.0 & I do not know about internet \\
Total & 780 & 100 & \\
\hline
\end{tabular}


Table 2. Opinions of the prospective teachers at PAU Education Faculty concerning their level of knowing about internet

\begin{tabular}{lllll}
\hline Nr & $\begin{array}{l}\text { Question } \\
n r\end{array}$ & The scaled question & Average & Meaning \\
\hline 1 & 1 & I!m capable of sending and receiving e-mail messages & 3.69 & I do know \\
2 & 2 & I'm capable of loading files and opening them & 3.63 & \\
3 & 6 & I know how to access internet & 3.49 & \\
4 & 4 & I'm capable of using interactive audiovisual communication means & 3.42 & \\
& & on internet & & \\
\hline 5 & 7 & I'm able to use internet means such as hyperlink & 3.23 & I know a \\
6 & 8 & I am able to use and make up a list of "ones frequently used". & 3.17 & little bit \\
7 & 3 & I'm capable of adding files or file transfer through FTP & 3.16 & \\
8 & 11 & I'm able to understand about advanced level of word processed & 2.87 & \\
& & functions as file transfer or perfection & & \\
9 & 10 & I could load and use audio-visial plug-ins & 2.73 & \\
10 & 5 & I know how to access an internet service provider (ISP) & 2.58 & I'm familiar \\
\hline 11 & 9 & I could change browser options & 2.50 & to some \\
& & & & extent \\
\hline
\end{tabular}

Table 3. Frequency values of the scores related to opinions of the prospective teachers at PAU Education Faculty concerning the resons for using internet

\begin{tabular}{llll}
\hline $\begin{array}{l}\text { Reasons for using } \\
\text { internet }\end{array}$ & Frequency & $\%$ & Level \\
\hline $4.21-5.00$ & 24 & 3.1 & Everday+ \\
$3.41-4.20$ & 126 & 16.2 & Everday \\
$2.61-3.40$ & 245 & 31.4 & Frequently \\
$1.81-2.60$ & 269 & 34.5 & Sometimes \\
$1.00-1.80$ & 116 & 14.9 & Never \\
TOTAL & 780 & 100 & \\
\hline
\end{tabular}


Table 4. Opinions of the prospective teachers at PAU Education faculty concerning the reasons for using internet

\begin{tabular}{lllll}
\hline $\mathrm{Nr}$ & $\begin{array}{l}\text { Question } \\
\mathrm{nr}\end{array}$ & The scaled question & Average & Meaning \\
\hline 1 & 1 & Research on the internet & 3.77 & Everday \\
2 & 2 & E-mail & 3.54 & \\
\hline 3 & 5 & Chat & 3.35 & Frequently \\
4 & 9 & Media monitoring & 3.21 & \\
5 & 6 & Entertainment games & 2.90 & \\
6 & 8 & Education & 2.86 & \\
\hline 7 & 4 & Creating multi-media & 2.33 & Sometimes \\
8 & 7 & Partipication in discussion & 2.32 & \\
\hline 9 & 3 & Web page publishing & 1.79 & Never \\
10 & 10 & E-commerce & 1.57 & \\
\hline
\end{tabular}

Table 5. Gender variations of the prospective teacher's opinions concerning their levels in knowing about internet

\begin{tabular}{llllll}
\hline Groups & $\mathrm{N}$ & $\mathrm{X}$ & $\mathrm{Ss}$ & $\mathrm{t}$ & $\mathrm{p}$ \\
\hline Female & 429 & 3.06 & .69 & -2.625 & $.009^{*}$ \\
Male & 351 & 3.19 & .66 & & \\
\hline$* p<.05$ & & & & &
\end{tabular}

Table 6.Variations, based on educational status, in opinions of prospective teachers at PAU Education Faculty concerning the levels of knowing about internet

\begin{tabular}{llllll}
\hline Groups & $\mathrm{N}$ & $\mathrm{X}$ & $\mathrm{Ss}$ & $\mathrm{t}$ & $\mathrm{p}$ \\
\hline $\begin{array}{l}\text { Normal } \\
\text { education }\end{array}$ & 417 & 3.11 & .69 & -.331 & $.740^{*}$ \\
$\begin{array}{l}\text { Nightshift } \\
\text { education }\end{array}$ & 363 & 3.12 & .68 & & \\
\hline${ }^{*} p<.05$ & & & & & \\
\hline
\end{tabular}


Table 7. Opinions the prospective teachers at PAU Education Faculty, based on their grade, concerning their level of knowing about internet

\begin{tabular}{|c|c|c|c|}
\hline Groups & $\mathrm{N}$ & $\mathrm{X}$ & Ss \\
\hline 1. class & 172 & 2.97 & .71 \\
\hline 2. class & 179 & 3.06 & .69 \\
\hline 3. class & 182 & 3.13 & .64 \\
\hline 4. class & 183 & 3.24 & .68 \\
\hline $5+\mathrm{y} 1 \mathrm{l}$ & 12 & 3.44 & .55 \\
\hline Without thesis MA & 37 & 3.26 & .65 \\
\hline Master thesis & 15 & 3.01 & .78 \\
\hline
\end{tabular}

Table 8. Variations, based on their grade, in opinions of prospective teachers at PAU Education Faculty concerning the levels of knowing about internet (ANOVA)

\begin{tabular}{llllll}
\hline $\begin{array}{l}\text { The source of } \\
\text { variance }\end{array}$ & Sd & $\begin{array}{l}\text { Sum of } \\
\text { Squares }\end{array}$ & Mean Square & F & P (Sig) \\
\hline $\begin{array}{l}\text { Between } \\
\text { Groups }\end{array}$ & 6 & 9.220 & 1.537 & 3.313 & $.003^{*}$ \\
Within Groups & 773 & 358.526 & .464 & & \\
Total & 779 & 367.746 & & & \\
$* p<.05$ & & & & &
\end{tabular}

Table 9. Based on their departments, opinions of the prospective teachers at PAU Education Faculty

\begin{tabular}{llll}
\hline Groups & $\mathrm{N}$ & $\mathrm{X}$ & $\mathrm{Ss}$ \\
\hline Phychological Advisory & 40 & 3.27 & .65 \\
Teaching of art & 75 & 3.04 & .80 \\
Teaching of music & 33 & 3.31 & .67 \\
Teaching of primary school & 262 & 3.17 & .64 \\
Teaching of science & 118 & 3.19 & .58 \\
Teaching of social sciences & 67 & 2.78 & .74 \\
Teaching of preschool education & 71 & 3.13 & .70 \\
Teaching of Turkish & 77 & 2.91 & .70 \\
Teaching of English & 37 & 3.28 & .63 \\
\hline
\end{tabular}


Table 10. Here is the variance analysis, based on their departments, about levels of the prospective teachers in knowing about internet (ANOVA)

\begin{tabular}{lclccc}
\hline $\begin{array}{l}\text { The source of } \\
\text { variance }\end{array}$ & Sd & $\begin{array}{l}\text { Sum of } \\
\text { Squares }\end{array}$ & Mean Square & F & $p$ \\
\hline Between & 8 & 15.705 & 1.963 & 4.299 & $.000^{*}$ \\
Groups & & & & & \\
Within Groups & 771 & 352.041 & .457 & & \\
Total & 779 & 367.746 & & & \\
$* p<.05$ & & & & &
\end{tabular}

Table 11. Based on school they graduated, opinions of the prospective teachers at PAU Education faculty concerning their knowledge in knowing about internet

\begin{tabular}{llll}
\hline Groups & $\mathrm{N}$ & $\mathrm{X}$ & $\mathrm{Ss}$ \\
\hline General and Anatolian High & 666 & 3.11 & .67 \\
Schools & & & \\
Occupational High Schools & 62 & 2.98 & .76 \\
License & 52 & 3.30 & .68 \\
\hline
\end{tabular}

Table 12. The variance analysis about opinions of the prospective teachers, based on the school they graduated about their levels in knowing about internet (ANOVA)

\begin{tabular}{llllll}
\hline $\begin{array}{l}\text { The source of } \\
\text { variance }\end{array}$ & Sd & $\begin{array}{l}\text { Sum of } \\
\text { Squares }\end{array}$ & Mean Square & F & p \\
\hline Between & 2 & 2.893 & 1.447 & 3.081 & $.046^{*}$ \\
Groups & & & & & \\
Within Groups & 777 & 364.853 & .470 & & \\
Total & 779 & 367.746 & & & \\
\hline$p<.05$ & & & & &
\end{tabular}

Table 13. Opinions of the prospective teachers, based on the place they access to internet, their levels in knowing about internet

\begin{tabular}{|c|c|c|c|}
\hline Groups & $\mathrm{N}$ & $\mathrm{X}$ & Ss \\
\hline Connection at home & 233 & 3.24 & .64 \\
\hline Connectionin in the university & 50 & 2.78 & .73 \\
\hline Connection in internet cafes & 160 & 2.79 & .69 \\
\hline $\begin{array}{l}\text { Connection both at home and in the } \\
\text { university }\end{array}$ & 76 & 3.31 & .56 \\
\hline $\begin{array}{l}\text { Connection both at home and in the } \\
\text { university and in internet cafes }\end{array}$ & 141 & 3.38 & .60 \\
\hline $\begin{array}{l}\text { Connection both in the university } \\
\text { and in internet cafes }\end{array}$ & 120 & 3.01 & .66 \\
\hline
\end{tabular}


Table 14. Variance analysis about the opinions of the prospective teachers, based on the place they connect to internet, about their levels in knowing about internet (ANOVA)

\begin{tabular}{lllccc}
\hline $\begin{array}{l}\text { The source of } \\
\text { variance }\end{array}$ & $\mathrm{Sd}$ & $\begin{array}{l}\text { Sum of } \\
\text { Squares }\end{array}$ & Mean Square & $\mathrm{F}$ & $\mathrm{p}$ \\
\hline $\begin{array}{l}\text { Between } \\
\text { Groups }\end{array}$ & 5 & 39.855 & 7.971 & 18.816 & $.000^{*}$ \\
Within Groups & 774 & 327.892 & .424 & & \\
Total & 779 & 367.746 & & & \\
\hline
\end{tabular}

$* p<.05$

Table 15. Opinions of the prospective teachers, based on for how many years they have connected to internet, concerning their levels in knowing about internet

\begin{tabular}{llll}
\hline Groups & $\mathrm{N}$ & $\mathrm{X}$ & $\mathrm{Ss}$ \\
\hline For 1 year & 146 & 2.81 & .68 \\
For 2 years & 131 & 2.96 & .70 \\
For 3 years & 140 & 3.05 & .64 \\
For 4 years & 134 & 3.19 & .67 \\
For 5+ years & 229 & 3.39 & .59 \\
\hline
\end{tabular}

Table 16. The variance analysis about opinions of prospective teachers, based on for how many years they have connected to internet, concerning their levels in knowing about internet (ANOVA)

\begin{tabular}{lllccc}
\hline $\begin{array}{l}\text { The source of } \\
\text { variance }\end{array}$ & $\mathrm{Sd}$ & $\begin{array}{l}\text { Sum of } \\
\text { Squares }\end{array}$ & Mean Square & $\mathrm{F}$ & $\mathrm{p}$ \\
\hline Between & 4 & 35.826 & 8.956 & 20.912 & $.000^{*}$ \\
Groups & & 331.921 & .428 & & \\
Within Groups & 775 & 367.746 & & & \\
Total & 779 & & & & \\
\hline
\end{tabular}

$* p<.05$

Table 17. Opinions of the prospective teachers, based on the duration on the internet a day, concerning their levels in knowing about internet

\begin{tabular}{llll}
\hline Groups & $\mathrm{N}$ & $\mathrm{X}$ & Ss \\
\hline Less than 1 hour & 123 & 2.66 & .70 \\
Between 1-2 hours & 413 & 3.05 & .64 \\
Between 3-4 hours & 157 & 3.41 & .56 \\
Between 5-6 hours & 42 & 3.45 & .60 \\
$7+$ hours & 45 & 3.63 & .51 \\
\hline
\end{tabular}

Table 18. The variance analysis about the opinions of the prospective teachers, based on the duration on the internet a day, concerning their levels in knowing about internet (ANOVA)

\begin{tabular}{llcccc}
\hline $\begin{array}{l}\text { The source of } \\
\text { variance }\end{array}$ & $S d$ & Sum of Squares & Mean Square & $F$ & $p$ \\
\hline $\begin{array}{l}\text { Between } \\
\text { Groups }\end{array}$ & 4 & 58.152 & 14.538 & 36.393 & $.000^{*}$ \\
Within Groups & 775 & 309.594 & .399 & \\
Total & 779 & 367.746 & & \\
$* p<.05$ & & & &
\end{tabular}

